\title{
Sensitivitas Bakteri Penyebab Sepsis Neonatorum terhadap Meropenem di Neonatal Intensive Care Unit dan Perinatologi RSUP DR M Djamil Padang Padang Tahun 2012
}

\author{
Susan Insani Putri, Aziz Djamal, Rahmatini
}

\begin{abstract}
Abstrak
Sepsis neonatorum merupakan salah satu penyebab kematian terbanyak pada neonatus. Manifestasi klinis sepsis neonatorum stadium dini tidak spesifik sehingga sulit dibedakan dari masalah neonatus lainnya. Meropenem merupakan antibiotika lini ketiga dengan ultra broad spectrum. Meropenem banyak digunakan dibeberapa instalasi RSUP DR M Djamil Padang terutama di bagian perinatologi dan Neonatal Intensive Care Unit (NICU) untuk mengobati infeksi berat seperti sepsis. Penelitian ini telah dilaksanakan pada bulan Juni 2013 sampai Desember 2013 di bagian Rekam Medik RSUP DR M Djamil Padang. Tujuannya untuk mengetahui bakteri penyebab sepsis neonatorum serta sensitivitasnya terhadap meropenem. Penelitian ini merupakan studi deskriptif yang bersifat cross-sectional. Dari hasil penelitian ditemukan bakteri penyebab sepsis neonatorum adalah Klebsiella sp. (79.2\%) diikuti oleh Staphylococcus aureus dan Pseudomonas aerogenosa masing-masing sebanyak (5.7\%), E. coli sebanyak (3.8\%), Proteus mirabilis, Staphylococcus epidermidis serta Streptococcus alfa hemoliticus masing-masing (1.9\%). Persentase sensitivitas bakteri penyebab sepsis neonatorum terhadap meropenem sebesar $77.4 \%$. Disimpulkan bahwa bakteri penyebab terbanyak pada sepsis neonatorum adalah Klebsiella sp dan sensitivitas bakteri terhadap meropenem masih baik.
\end{abstract}

Kata kunci: Sepsis neonatorum, bakteri penyebab, meropenem

\begin{abstract}
Sepsis neonatorum is one of the diseases that cause the highest number of deaths in neonatal period. Because clinical manifestations of early onset sepsis neonatorum is not specific, it is quite difficult to differentiate it from other neonatal problems. Meropenem is a third line antibiotics with ultra-broad spectrum. It is widely used in many installations at RSUP DR M. Djamil especially in the section of perinatology and Neonatal Intensive Care Unit (NICU) to treat severe infections such as sepsis. This research was conducted from June 2013 until December 2013 at Medical Record Section of RSUP DR M. Djamil Padang. The goal of this research is to discover which bacterium causes sepsis neonatorum and its sensitivity to meropenem. This research is a cross-sectional descriptive study. According to the research result, bacteria that cause sepsis neonatorum are Klebsiella sp. (79.2\%), Staphylococcus aureus (5.7\%), Pseudomonas aerogenosa (5.7\%), E. coli (3.8\%), Proteus mirabilis (1.9\%), Staphylococcus epidermis (1.9\%) and Streptococcus alfa hemoliticus (1.9\%). These bacteria has $77.4 \%$ sensitivity to meropenem. It can be concluded that the bacteria which cause the highest number of sepsis neonatorum cases is Klebsiella sp. and still has good sensitivity to meropenem.
\end{abstract}

Keyword: Sepsis neonatorum, bacteria, meropenem

Affiliasi penulis : Fakultas Kedokteran Universitas andalas Korespondensi : Susan Insani Putri, email: susan.insani@gmail.com, Telp: 081363932691

\section{PENDAHULUAN \\ World Health Organization \\ (WHO)}

memperkirakan secara global setiap tahun terdapat 5 
juta bayi meninggal pada usia empat minggu pertama kehidupannya, dengan 98\% kematian tersebut berasal dari negara berkembang. Angka kematian bayi $50 \%$ terjadi pada periode neonatus dan $50 \%$ terjadi pada minggu pertama kehidupan. ${ }^{1}$ Salah satu penyebab kematian terbanyak pada bayi adalah sepsis neonatorum. Insiden sepsis neonatorum di negara maju sebesar 1 sampai 4 dari 1000 kelahiran hidup dengan angka kematian $10.3 \%$ dan dinegara berkembang sebesar 10 sampai 50 dari 1000 kelahiran hidup dengan angka kematian $12-68 \%{ }^{2}$

Sepsis neonatorum merupakan istilah yang menggambarkan respon sistemik terhadap infeksi berat pada bayi baru lahir dengan kultur darah positif pada empat minggu pertama kehidupan neonates. ${ }^{3}$ Pola kuman penyebab sepsis berbeda-beda antar negara dan selalu berubah dari waktu ke waktu. Bahkan di negara berkembang sendiri ditemukan perbedaan pola kuman, walaupun bakteri Gram negatif rata-rata menjadi penyebab utama dari sepsis neonatorum. Perbedaan pola kuman ini akan mempengaruhi tata laksana sepsis dalam hal pemilihan antibiotika, prognosis dan komplikasi yang akan terjadi. ${ }^{4}$

Berbagai studi menemukan bahwa sekitar 40 - 62\% antibiotika digunakan secara tidak tepat antara lain pada penyakit-penyakit yang sebenarnya tidak memerlukan antibiotika. Pada penelitian kualitas penggunaan antibiotika di berbagai bagian rumah sakit ditemukan 30\% - 80\% tidak didasarkan pada indikasi. Intensitas penggunaan antibiotika yang relatif tinggi menimbulkan berbagai permasalahan dan merupakan ancaman global bagi kesehatan terutama resistensi bakteri terhadap antibiotika. ${ }^{5}$

Meropenem merupakan antibiotika ultra broad spectrum golongan karbapenem yang diindikasikan untuk bakteri Gram positif, Gram negatif dan anaerob. ${ }^{6}$ Meropenem banyak digunakan dibeberapa instalasi RSUP DR M Djamil Padang terutama di bagian perinatologi dan Neonatal Intensive Care Unit (NICU) untuk mengobati infeksi berat seperti sepsis. Berdasarkan survei pendahuluan, dari 50 status pasien yang didiagnosis sepsis neonatorum didapatkan 36 pasien yang menggunakan meropenem. Meropenem seharusnya menjadi antibiotika pilihan terakhir untuk mengobati infeksi yang sangat berat. Apabila pemakaiannya tidak sesuai dengan indikasi maka dapat menyebabkan resistensi terhadap meropenem dan pengobatan selanjutnya akan lebih sulit serta akan memberatkan pasien karena harga antibiotika meropenem cukup mahal.

\section{METODE}

Penelitian ini merupakan penelitian crosssectional dengan mengambil data dari status rekam medik pasien sepsis neonatorum di Intalasi rekam medik dan data pemeriksaan kultur darah di laboratorium mikrobiologi RSUP DR M. Djamil Padang periode 1 Januari 2012 - 31 Desember 2012, dengan diagnosis sepsis neonatorum. Subyek penelitian ini adalah semua bayi sepsis dengan data rekam medis lengkap, didapatkan hasil kultur dan uji kepekaan kuman. Data yang didapatkan diolah secara manual untuk mengetahui insiden sepsis neonatorum, persentase jenis kuman penyebab sepsis neonatorum dan persentase sensitivitas antibiotika meropenem terhadap bakteri penyebab sepsis neonatorum. Hasil pengamatan yang diperoleh akan disajikan dalam bentuk gambar dan tabel.

\section{HASIL}

Pada periode Januari - Desember 2012 dari 863 orang yang dirawat di ruang Neonatal Intensive Care Unit (NICU) dan Perinatologi, 290 orang diantaranya menderita sepsis neonatorum sehingga didapatkan insiden sepsis neonatorum sebesar $33.6 \%$.

Dari 290 orang pasien yang didiagnosis sepsis neonatorum didapatkan persentase pasien yang diperiksa kultur darah sebesar $87.9 \%$ dan pasien yang tidak dilakukan pemeriksaan kultur darah sebesar $12.1 \%$. Jumlah pasien dengan hasil kultur darah positif sebanyak 53 orang. Ditemukan bakteri penyebab sepsis neonatorum terbanyak adalah Klebsiella sp sebanyak (79.2\%) diikuti oleh Staphylococcus aureus dan Pseudomonas aerogenosa masing-masing sebanyak (5.7\%). E. Coli sebanyak (3.8\%). Proteus mirabilis, Staphylococcus epidermidis, serta Streptococcus alfa hemoliticus masing-masing (1.9\%) (Lihat tabel 1). 
Tabel 1. Pola kuman sepsis neonatorum di RSUP Dr.

M. Djamil Padang tahun 2012

\begin{tabular}{lc}
\hline \multicolumn{1}{c}{ Jenis mikroorganisme } & Jumlah \\
\hline Klebsiella $s p$ & 42 \\
Staphylococcus aureus & 3 \\
Pseudomonas aerogenosa & 3 \\
E. coli & 2 \\
Proteus mirabilis & 1 \\
Staphylococcus epidermidis & 1 \\
Streptococcus alfa hemolitikus & 1 \\
\multicolumn{1}{c}{ Total } & $\mathbf{5 3}$ \\
\hline
\end{tabular}

Tabel 2. Sensitivitas antibiotika meropenem terhadap bakteri penyebab sepsis neonatorum

\begin{tabular}{lllll}
\hline \multirow{2}{*}{ Jenis mikroorganisme } & \multicolumn{3}{c}{ Meropenem } \\
\cline { 2 - 5 } & $\mathbf{S}$ & $\mathbf{I}$ & $\mathbf{R}$ & $\begin{array}{l}\text { Tidak ada } \\
\text { data }\end{array}$ \\
\hline Klebsiella $s p$ & 34 & 2 & 5 & 1 \\
\hline Staphylococcus aureus & 3 & 0 & 0 & 0 \\
\hline Pseudomonas aerogenosa & 2 & 0 & 1 & 0 \\
\hline E. coli & 2 & 0 & 0 & 0 \\
\hline Proteus mirabilis & 0 & 0 & 1 & 0 \\
\hline Staphylococcus epidermidis & 0 & 0 & 1 & 0 \\
\hline Streptococcus alfa hemolitikus & 0 & 0 & 1 & 0 \\
\hline Total & $\mathbf{4 1}$ & $\mathbf{2}$ & $\mathbf{9}$ & $\mathbf{1}$ \\
\hline
\end{tabular}

Sensitivitas meropenem terhadap bakteri penyebab terbanyak sepsis neonatorum yaitu Klebsiella $s p$ sebesar $80.8 \%$ (Lihat tabel 2).

\section{PEMBAHASAN}

Insiden sepsis neonatorum di RSUP DR M Djamil Padang periode 1 Januari 2012 - 31 Desember 2012 cukup tinggi. Hal ini salah satunya disebabkan oleh masih banyaknya sumber infeksi yang didapat oleh bayi baru lahir baik dari jalan lahir ibu maupun didapat dari lingkungan sekitar atau rumah sakit (infeksi nosokomial). ${ }^{4}$ Pada Januari 2010 Desember 2010 di Rumah sakit Sanglah ditemukan insiden sepsis neonatorum sebesar $5 \%{ }^{7}$ Insiden sepsis neonatorum beragam pada setiap rumah sakit. Hal ini dihubungkan dengan angka prematuritas, perawatan prenatal, penatalaksanaan persalinan, dan kondisi lingkungan di ruang perawatan. ${ }^{8}$

Biakan darah positif terdapat pada $20.8 \%$ subyek, lebih sedikit dibandingkan dengan data dari RS Cipto Mangunkusumo Jakarta periode Juli 2004 Mei 2005 sebesar $65.26 \%$ yang menggunakan media kultur bactec. ${ }^{9}$ Sedangkan pada tempat yang sama periode Desember 2006 - Juli 2007 didapatkan hasil kultur positif sebesar $41.2 \% .^{10}$ Hasil kultur positif di RSUP Sanglah Denpasar sebesar 48\%. Hasil biakan negatif dapat disebabkan oleh volume darah yang diambil untuk kultur terlalu sedikit, pemberian antibiotika profilaksis pada ibu hamil dan bayi baru lahir, pemberian antibiotika sebelum biakan darah diambil, dan mungkin sepsis disebabkan oleh bakteri anaerob yang sulit tumbuh. ${ }^{11}$ Beberapa faktor yang dapat menentukan apakah biakan darah akan memberikan hasil positif yaitu volume darah yang dibiakkan, pengenceran darah dalam pembenihan biakan, penggunaan pembenihan biakan aerobik dan anaerobik serta lamanya inkubasi. ${ }^{12}$ Pada penelitian ini, hasil kultur darah negatif salah satunya disebabkan oleh pengambilan sampel darah yang sulit.

Pada penelitian ini, bakteri Gram negatif sebagai penyebab sepsis jauh lebih tinggi dibanding Gram positif (90.6\% versus $9.4 \%$ ). Penelitian Kardana di RSUP Sanglah Denpasar tahun 2008-2009 didapatkan perbandingan bakteri Gram negatif dengan Gram positif sebesar $68.3 \%$ versus $31.7 \%$. Di negara berkembang, bakteri Gram negatif rata-rata menjadi penyebab utama sepsis neonatorum. ${ }^{4}$

Penelitian sebelumnya di RSUP DR $M$. Djamil Padang pada periode 1 Januari - 31 Desember 2009 oleh Mayetti dan led Imilda, didapatkan bakteri penyebab sepsis neonatorum terbanyak adalah Staphylococcus aureus (32.6\%), diikuti oleh Klebsiella sp dan Enterobacter sp (masingmasing 22.6\%). ${ }^{13}$ Di RS Cipto Mangunkusumo periode Desember 2006 - Juli 2007 seperti yang dilaporkan Juniatiningsih dkk. didapatkan bakteri penyebab sepsis neonatorum terbanyak Acinetobacter calcoaceticus (14.7\%), diikuti oleh Staphylococcus epidermidis (6.9\%), Enterobacter aerogens (4.9\%). ${ }^{10}$ Di RSUP Sanglah Denpasar periode 1 Januari 2008 - 31 Desember 2009 ditemukan bakteri terbanyak penyebab sepsis neonatorum adalah Serratia marcescens (23.5\%), Staphylococcus coagulase positive (16.4\%) dan Staphylococcus coagulase negative (10.7\%). ${ }^{11}$ Di RSUP H. Adam Malik Medan periode Januari 2008 - Desember 2010 ditemukan bakteri penyebab sepsis neonatorum yang terbanyak adalah Staphylococcus sp diikuti Pseudomonas sp dan 
Enterobacter $s p{ }^{1}$ Perbedaan pola kuman tersebut disebabkan oleh berbagai hal seperti tingginya insiden kolonisasi kuman pada ibu, perbedaan pola kuman di lingkungan ibu dan bayi, perbedaan respon imun dan faktor genetik dari populasi, perbedaan cara analisis mikrobiologis, perbedaan tingkat pendidikan dan pelayanan kesehatan serta perubahan pola antibiotika dan gaya hidup. ${ }^{8}$

Pola kuman penyebab sepsis neonatorum pada penelitian ini didominasi oleh kuman Enterobacteriaceae yaitu Klebsiella sp (79.2\%), Pseudomonas aerogenosa (5.7\%), E. Coli (3.8\%) dan Proteus mirabilis (1.9\%). Sebanyak $80 \%$ dari kuman batang Gram negatif yang disolasi di laboratorium Mikrobiologi Klinik adalah kuman Enterobacteriaceae dan $50 \%$ dari jumlah tersebut adalah isolat yang berasal dari bahan klinik. Organisme dalam famili ini mempunyai peranan penting dalam infeksi nosocomial. $^{14}$ Dari hasil uji sensitivitas, secara keseluruhan didapatkan sensitivitas antibiotika meropenem terhadap bakteri penyebab sepsis neonatorum masih baik (77.4\%). Di RS Cipto Mangunkusumo periode Februari 2006 - 13 Juni 2006 ditemukan meropenem masih mempunyai sensitivitas cukup baik terhadap bakteri Gram negatif yaitu 66.67 $100 \%$ dan bakteri Gram positif $66.67 \% .^{15}$ Di RSUP Sanglah Denpasar ditemukan bakteri penyebab sepsis neonatorum mempunyai sensitivitas yang rendah terhadap antibiotika lini pertama (ampisilin dan gentamisin) yaitu sekitar $0-57.1 \%$. Sedangkan pada sebagian besar bakteri penyebab sepsis neonatorum mempunyai sensitivitas yang tinggi terhadap meropenem. Di RS Dr Moewardi Surakarta, dilaporkan sensitivitas terhadap meropenem adalah Enterobacter (73.3\%), Staphylococcus (25\%) dan Citrobacter $(100 \%) .{ }^{11}$ Penelitian sebelumnnya yang dilakukan di RSUP DR M. Djamil Padang periode 1 Januari - 30 Juni 2009 didapatkan sensitivitas meropenem terhadap Staphylococcus aureus (18.7\%), Klebsiella sp (58.3\%), dan Enterobacter sp (83.3\%). ${ }^{13}$

\section{KESIMPULAN}

1. Insiden sepsis neonatorum masih tinggi di RSUP DR M. Djamil Padang.

2. Klebsiella sp. merupakan kuman yang paling sering ditemukan pada sepsis neonatorum.

3. Sensitivitas bakteri penyebab sepsis neonatorum terhadap meropenem masih baik

\section{DAFTAR PUSTAKA}

1. Sianturi Pertin, Beby S. Hasibuan, dkk. Gambaran Pola Resistensi Bakteri di Unit Pelayanan Neonatus. Sari Pediatri. 2011; 13: 431-6.

2. Wilar Rocky, Ellen Kumalassari, Diana Yuliani. Faktor resiko sepsis awitan dini. Sari pediatri. 2010; 12:265-9.

3. Gotoff SP. Infections of the neonatal infant. Dalam:

4. Behrman RE, Kliegman RM, Jenson $H B$, editor (penyunting). Textbook of Pediatrics. Edisi ke-15. Philadelphia: WB Saunders; 2000. HIm. 653-5.

5. Departemen kesehatan RI. Penatalaksanaan sepsis neonatorum. Jakarta: Departemen Kesehatan Republik Indonesia. 2007.

6. Peraturan Menteri kesehatan Republik Indonesia. Pedoman Umum Penggunaan Antibiotika. Jakarta: Departemen Kesehatan RI. 2011.

7. Mohanty. Guideslines For Antimicrobial Therapy 2011. Safdarjang Hospital. 2011.

8. Putra Putu Junara. Insiden dan Faktor yang Berhubungan Dengan Sepsis Neonatorum di RSUP Sanglah Denpasar. Sari pediatri. 2012; 14: $205-10$

9. Aminullah A. Masalah terkini sepsis neonatorum. Dalam: Hegar B, Partini PP, Bermansyah EB, editor (penyunting). Update in neonatal infection. Jakarta: Departemen IImu Kesehatan Anak FKUIRSCM; 2005. HIm. 1-15.

10. Rohsiswatmo R. Multidrug resistance in a neonatal unit and therapeutic implications. Paediatrica Indonesiana. 2006; 46: 25-31.

11. Juniatiningsih A, Aminullah A, Firmansyah A. Profil mikroorganisme penyebab sepsis neonatorum di Departemen IImu kesehatan Anak Rumah sakit Ciptomangunkusumo. Sari pediatri. 2008; 10: 60-5 
12. Kardana I Made. Pola kuman dan sensitivitas antibiotika di ruang perinatologi. Sari pediatri. 2011; 12: 381-5.

13. Jawetz E, Melnick JL, Adelberg E. Mikrobiologi Kedokteran. Edisi ke-20. Jakarta: EGC; 2007.

14. Mayetti, led Imilda. 2010. Pola bakteriologis dan uji sensitivitas pada sepsis neonatorum awitan dini. Sari pediatri. 2010; 11: 326-9.

15. Karsinah, Lucky H.M, Suharto, Mardiastuti. Batang Negatif Gram. Dalam: Agus Syahrurachman, dkk, editor (penyunting). Buku Ajar Mikrobiologi Kedokteran. Jakarta: Binarupa Aksara Publisher; 2009. HIm. 211-4. 